\title{
In vitro culture and diversity of endophytic fungi in Bambusa oldhamii ${ }^{1}$
}

\author{
Ana Paula de Azevedo Pasqualini ${ }^{2}$, Mariely Cristine dos Santos ${ }^{3}$, \\ Bruno Francisco Sant'Anna-Santos ${ }^{4}$, Hugo Pacheco de Freitas Fraga ${ }^{4}$, Marguerite Quoirin ${ }^{4}$
}

\section{ABSTRACT}

Bambusa oldhamii Munro is a fast-growing species of woody bamboo with strong commercial appeal. In Brazil, the use of this species is limited, mainly due to the low availability of seedlings for commercial plantations. Micropropagation is a technique used for the large scale production of seedlings, but protocols for the establishment of aseptic cultures are hampered by the presence of endophytic contamination. This study aimed to develop an in vitro establishment protocol for B. oldhamii, as well as to make the molecular identification of fungi associated with the explants used. Nodal segments of adult plants grown in the field were used as explants. This material was submitted to two experiments carried out to evaluate the effect of 6-benzylaminopurine (BAP) on multiplication and of Plant Preservative Mixture $\left(\mathrm{PPM}^{\mathrm{TM}}\right)$ as a disinfectant. In the first one, $10 \mu \mathrm{M}, 15 \mu \mathrm{M}$ or $20 \mu \mathrm{M}$ of BAP were combined with $1 \mathrm{~mL} \mathrm{~L}^{-1}, 2 \mathrm{~mL} \mathrm{~L}^{-1}$ or $3 \mathrm{~mL} \mathrm{~L}^{-1}$ of $\mathrm{PPM}^{\mathrm{TM}}$; while the second one used $0 \mu \mathrm{M}, 2.5 \mu \mathrm{M}, 5 \mu \mathrm{M}$ or $7.5 \mu \mathrm{M}$ of BAP with $4 \mathrm{~mL} \mathrm{~L}^{-1}$ of $\mathrm{PPM}^{\mathrm{TM}}$, both added to MS culture medium. After 21 days of culture, the use of $4 \mathrm{~mL} \mathrm{~L}^{-1}$ of PPM ${ }^{\mathrm{TM}}$ inhibited the bacterial growth and reduced fungal contamination. The addition of BAP to the culture medium above $10 \mu \mathrm{M}$ inhibited the formation and growth of new shoots, while additions of less than 7,5 $\mu \mathrm{M}$ had no effect. The molecular identification of the endophytic fungi isolated during the in vitro culture indicated the presence of numerous fungal species, increasing the current knowledge about the diversity of fungi associated with bamboo.

KEYWORDS: Bamboo, 6-benzylaminopurine, micropropagation.

\section{INTRODUCTION}

Bamboos are part of the Poaceae family, Bambusoideae subfamily (Islam et al. 2011), and have wide applications in areas such as architecture, decoration, landscaping, recovery of degraded areas,

\section{RESUMO}

Cultura in vitro e diversidade de fungos endofíticos em Bambusa oldhamii

Bambusa oldhamii Munro é uma espécie de bambu lenhoso de crescimento rápido e com forte apelo comercial. No Brasil, o uso dessa espécie é limitado, devido, principalmente, à baixa disponibilidade de mudas para plantios comerciais. A micropropagação é uma técnica de produção de mudas em larga escala, porém, protocolos de estabelecimento de culturas assépticas são dificultados pela presença de contaminação endofítica. Objetivou-se desenvolver um protocolo de estabelecimento in vitro de B. oldhamii, bem como efetuar a identificação molecular de fungos associados aos explantes utilizados. Segmentos nodais de plantas adultas cultivadas a campo foram utilizados como explantes. Esse material foi submetido a dois experimentos, avaliando-se o efeito de 6-benzylaminopurine (BAP) na multiplicação e de Plant Preservative Mixture (PPM ${ }^{\mathrm{TM}}$ ) na desinfestação. No primeiro, foram utilizadas concentrações de BAP de $10 \mu \mathrm{M}, 15 \mu \mathrm{M}$ ou $20 \mu \mathrm{M}$, combinadas com $1 \mathrm{~mL} \mathrm{~L}^{-1}, 2 \mathrm{mLL}^{-1}$ ou $3 \mathrm{mLL}^{-1}$ de $\mathrm{PPM}^{\mathrm{TM}}$, e, no segundo, $0 \mu \mathrm{M}, 2,5 \mu \mathrm{M}, 5 \mu \mathrm{M}$ ou $7,5 \mu \mathrm{M}$ de BAP, com $4 \mathrm{~mL} \mathrm{~L}^{-1}$ de PPM ${ }^{\mathrm{TM}}$, ambos adicionados a meio de cultura MS. Após 21 dias de cultivo, o uso de $4 \mathrm{~mL} \mathrm{~L}^{-1}$ de $\mathrm{PPM}^{\mathrm{TM}}$ inibiu o crescimento bacteriano e reduziu a contaminação fúngica. A presença de BAP no meio de cultura acima de $10 \mu \mathrm{M}$ inibiu a formação e o crescimento de brotos novos, enquanto as concentrações inferiores a 7,5 $\mu \mathrm{M}$ não tiveram efeito. A identificação molecular dos fungos endofíticos isolados durante a cultura in vitro indicou a presença de inúmeras espécies fúngicas, ampliando o conhecimento sobre a diversidade de fungos associados ao bambu.

PALAVRAS-CHAVE: Bambu, 6-benzilaminopurina, micropropagação.

manufacturing of paper and food products, being considered an important forest resource (Chen et al. 2011).

The bamboo production chain is of great impact in several countries, but, in Brazil, its use is still very limited, considering its potential applications. In order

1. Received: Jul. 01, 2018. Accepted: Oct. 10, 2018. Published: Jun. 10, 2019. DOI: 10.1590/1983-40632019v4953760.

2. Universidade Federal do Paraná, Departamento de Fitotecnia e Fitossanidade, Curitiba, PR, Brasil.

E-mail/ORCID: anapauladeazevedo@gmail.com/0000-0002-1430-6495.

3. Universidade Tecnológica Federal do Paraná, Ponta Grossa, PR, Brasil. E-mail/ORCID: s.mariely.c@gmail.com/ 0000-0003-3063-9588.

4. Universidade Federal do Paraná, Departamento de Botânica, Curitiba, PR, Brasil.E-mail/ORCID: brunofrancisco@ufpr.br/ 0000-0002-8327-2081, hugofraga@ufpr.br/0000-0002-7363-5213, mquoirin@ufpr.br/0000-0003-3190-6895. 
to stimulate the use of this important forest resource, the law n. ${ }^{\circ} 12.484 / 2011$ established the National Politics on Incentive to Sustainable Management and Cultivation of Bamboo (NPMCB), with the objective of developing the production of bamboo by means of governmental actions and private ventures (Brasil 2011). However, traditional methods of bamboo propagation are unable to provide seedlings in quantities necessary for the establishment of clonal plantations to support a sustained production chain. Therefore, there is a need for the development of efficient methods to obtain propagules with in vitro culture (Shirin \& Rana 2007).

Among the bamboo species with economic potential is Bambusa oldhamii Munro, which is a semitropical species, native to Taiwan and southern China, with straight culm, 6-12 $\mathrm{m}$ in height, $3-9 \mathrm{~cm}$ in diameter, similar internodes and thornless (Shouliang et al. 2007). These characteristics favor its use in the manufacturing of products related to wood and in the production of edible shoots (Lin et al. 2007).

$B$. oldhamii micropropagation has been reported using somatic embryogenesis (Yeh \& Chang 1986), meristem culture (Lin et al. 2007) and nodal segments (Thiruvengadam et al. 2011). However, protocols for in vitro establishment from nodal segments originating from adult bamboo plants cultivated in the field are scarce (Mudoi \& Borthakur 2009). For tissue culture of the Bambusa species, especially in the case of nodal segments, the most serious problem is endophytic contamination (Abdulminam et al. 2009), which hinders the establishment of aseptic cultures due to the high diversity of fungi associated with this species (Tyagi et al. 2017).

When carrying out aseptic cultures of bamboo explants, the most commonly used sterilizing agents are ethanol, sodium chloride $(\mathrm{NaOCl})$ and mercury chloride $\left(\mathrm{HgCl}_{2}\right)$ (Goyal \& Sen 2016). Moreover, for the control of growth microorganisms, the addition of antibiotics (Abdulminam et al. 2009, Nadha et al. 2012), fungicides (Mishra et al. 2008, Tyagi et al. 2017) and biocides (Torres et al. 2016) to the culture medium have been reported.

Understanding the diversity of microorganisms associated with plant tissue allows the optimization of asseptic protocols aiming at reducing contamination rates and increasing in vitro survival rates. However, data about isolation and identification of bamboo fungi are still limited (Tyagi et al. 2017). In this context, scanning electron microscopy studies and molecular techniques may help to visualize and identify endophytic contaminants.

This study aimed to establish an aseptic protocol for the in vitro propagation of nodal segments from adult shoots of $B$. oldhamii cultivated in the field, as well as to identify endophytic fungi associated with this species.

\section{MATERIAL AND METHODS}

Lateral sprouts of B. oldhamii were collected from nine year-old plants, in Pinhais, Paraná state, Brazil (25'23'11.8'S and 4907'33.9''W), in February and August 2017. These trees were planted as part of an experimental design carried out by Mognon (2015). The sprouts had their apex and leaf sheaths removed, were cut in nodal segments of $2-3 \mathrm{~cm}$ in length containing a dormant bud and were used in two experiments. The explants were immersed in an aqueous solution containing $2 \mathrm{~g} \mathrm{~L}^{-1}$ of Cercobin ${ }^{\circledR}$ (thiophanate methyl) for $24 \mathrm{~h}$ and then disinfested with alcohol $70 \%$ (1 min), $\mathrm{HgCl}_{2} 0.1 \%$ (10 min) and $\mathrm{NaOCl} 1 \%$ (15 min), rinsed three times with sterile water and had their extremities excised.

The basal culture medium contained MS (Murashige \& Skoog 1962) salts and vitamins and $3 \%$ of sucrose. In the first experiment, the basal medium was supplemented with $0 \mu \mathrm{M}, 10 \mu \mathrm{M}$, $15 \mu \mathrm{M}$ or $20 \mu \mathrm{M}$ of BAP, combined with $0 \mathrm{~mL} \mathrm{~L}^{-1}$, $1 \mathrm{~mL} \mathrm{~L}^{-1}, 2 \mathrm{~mL} \mathrm{~L}^{-1}$ or $3 \mathrm{~mL} \mathrm{~L}^{-1}$ of $\mathrm{PPM}^{\mathrm{TM}}$ in a factorial scheme, with a total of 16 treatments, replicated three times, in a completely randomized design. The plots consisted of eight test tubes containing $10 \mathrm{~mL}$ of medium and one explant per tube. In the second experiment, the basal medium was supplemented with $0 \mu \mathrm{M}, 2.5 \mu \mathrm{M}, 5 \mu \mathrm{M}$ or $7.5 \mu \mathrm{M}$ of BAP and $4 \mathrm{~mL} \mathrm{~L}^{-1}$ of $\mathrm{PPM}^{\mathrm{TM}}$ in a completely randomized design, with a total of 4 treatments, replicated five times, with each plot consisting of eight test tubes containing $10 \mathrm{~mL}$ of medium and one explant each. The $\mathrm{pH}$ of the culture medium was adjusted to 5.8 before the addition of $6 \mathrm{~g} \mathrm{~L}^{-1}$ of agar $\left(\right.$ Synth $\left.^{\circledR}\right)$. The test tubes containing culture medium were sealed with plastic covers and autoclaved at $120^{\circ} \mathrm{C}$, for $20 \mathrm{~min}$. All components of the culture medium, including the $\mathrm{PPM}^{\mathrm{TM}}$, were added before autoclaving.

After the inoculation of the explants in the culture medium, the tubes were maintained at $25 \pm 2{ }^{\circ} \mathrm{C}$ in the absence of light for 10 days and then placed 
under fluorescent white light with a photosynthetic photon flux density of $30 \mu \mathrm{mol} \mathrm{m} \mathrm{m}^{-2} \mathrm{~s}^{-1}$ and photoperiod of $16 \mathrm{~h}$.

After a period of three weeks, the following parameters were analyzed: percentage of explants with shoots per treatment; average number of shoots per explant and average length of shoots; and percentages of bacterial contamination, fungal contamination, total microbial contamination and of surviving explants. Percentage data were transformed by $\operatorname{arc} \operatorname{sen} \sqrt{ }(x / 100)$. The effect of the treatments was evaluated by analysis of variance (Anova) and, when significant, the averages of the treatments were compared statistically by the Tukey test at $5 \%$ of significance and analyzed by polynomial regression with the aid of the Assistat software (Silva \& Azevedo 2016).

For the analysis by scanning electron microscopy, explants of approximately $0.5 \mathrm{~cm}$ in length were used. The samples were fixed using FAA $_{70}$ (formaldehyde solution $47 \%$, acetic acid and ethanol $70 \%, 1: 1: 18 \mathrm{v} / \mathrm{v}$ ) (Johansen 1940). The samples were dehydrated in ethanol and subsequently dried to achieve their critical-point under $\mathrm{CO}_{2}$ (Bal-Tec CPD 030). After metallization with gold in a metallizer (Balzers Union FL 9496 SCD 030), the images were obtained by scanning electron microscopy Jeol (JSM 6360 LV).

After 28 days of in vitro culture, the fungal contaminants of nodal segments of the second experiment were identified. Samples were selected and previously classified by macromorphology colony (shape, texture, pigments and color). The fungi were isolated and the colonies purified in a PDA (potato + dextrose + agar) culture medium. Fungal incubation was carried out in a BOD incubator at $25{ }^{\circ} \mathrm{C}$, with photoperiod of $12 \mathrm{~h}$, for 15 days. The cultures were also deposited in the collection of the Universidade Tecnológica do Paraná, in Ponta Grossa, Paraná state, Brazil, and maintained in the Coleções Microbiológicas da Rede Paranaense (CMRP).

The total genomic DNA of representative strains for each morphotype was extracted according to the protocol established by Vicente et al. (2008). The DNA quality and viability were evaluated by electrophoresis in a $0.8 \%$ agarose gel. For the amplification reaction (PCR) of the $18 \mathrm{~S} \mathrm{rDNA}$ gene, oligonucleotides ITS1 e ITS4 (Badali et al. 2008) were used with a final reaction volume of $25 \mu \mathrm{L}$, carried out under the following conditions: $95{ }^{\circ} \mathrm{C}$ for $5 \mathrm{~min}, 35$ cycles of $94^{\circ} \mathrm{C}$ for $45 \mathrm{~s}, 52^{\circ} \mathrm{C}$ for $45 \mathrm{~s}$ and $72{ }^{\circ} \mathrm{C}$ for $2 \mathrm{~min}$, with a final step of $72{ }^{\circ} \mathrm{C}$ for 7 min. The amplification products were separated by electrophoresis in a $1.4 \%$ agarose gel $(70 \mathrm{~V}$ for 30 min). The agarose gels were stained with ethidium bromide and observed using a transilluminator.

The PCR products were then purified and sequenced in the automated sequencer ABI 3730 (Applied Biosystems) by Myleus Biotechnology. The sequences were downloaded and treated with the Bioedit software version 7.0 (Hall 1999). The sequences were then compared with those deposited in the National Center for Biotechnology Information (NCBI), using the Basic Local Alignment Search Tool, aiming to identify the isolates by similarity with the sequences contained in the database.

\section{RESULTS AND DISCUSSION}

The results for analysis of variance of the data from the first experiment are presented in Table 1, where the media was supplemented with BAP $(0 \mu \mathrm{M}, 10 \mu \mathrm{M}, 15 \mu \mathrm{M}$ or $20 \mu \mathrm{M})$ and $\mathrm{PPM}^{\mathrm{TM}}$ $\left(0 \mathrm{~mL} \mathrm{~L}^{-1}, 1 \mathrm{~mL} \mathrm{~L}^{-1}, 2 \mathrm{~mL} \mathrm{~L}^{-1}\right.$ or $\left.3 \mathrm{~mL} \mathrm{~L}^{-1}\right)$. According to the results, there was no significant interaction between the factors, except for the survival rate of explants.

The percentage of explants with shoots per treatment, average length of shoots and percentage of fungal contamination were significantly affected by the BAP concentrations $(0 \mu \mathrm{M}, 10 \mu \mathrm{M}, 15 \mu \mathrm{M}$ or $20 \mu \mathrm{M}$ ) (Table 1). Among these variables, only the percentage of explants with shoots per treatment and the average length of shoots showed linear inverse correlation with the evaluated BAP concentrations, as indicated by the regression analysis (Figures 1A and $1 \mathrm{~B}$ ). In relation to the variable average number of shoots per explant, there was no significant difference between treatments (Figure 1C).

Based on the data shown here, it is possible to infer that the supplementation of the culture medium with $20 \mu \mathrm{M}$ of BAP inhibited the development of shoots, when compared to the control treatment (without the addition of BAP), since the percentage of explants with shoots was reduced from $40 \%$ to $22 \%$ (Figure 1A) and the average length of shoots from $1.0 \mathrm{~cm}$ to $0.4 \mathrm{~cm}$ (Figure 1B). Moreover, the addition of BAP to the culture medium did not induce the development of multiple sprouts, as there was 
Table 1. Analysis of variance for the effect of BAP and $\mathrm{PPM}^{\mathrm{TM}}$ on Bambusa oldhamii explants cultivated in MS culture medium for 21 days.

\begin{tabular}{|c|c|c|c|c|c|}
\hline \multirow{2}{*}{ Sources of variation } & \multirow{2}{*}{ DF } & \multicolumn{4}{|c|}{ Mean square } \\
\hline & & PEST (\%) & \multicolumn{2}{|c|}{ NSE } & $\mathrm{LS}(\mathrm{cm})$ \\
\hline BAP & 3 & $0.2395 * *$ & \multicolumn{2}{|c|}{$0.1389^{\mathrm{ns}}$} & $0.8809 * *$ \\
\hline $\mathrm{PPM}^{\mathrm{TM}}$ & 3 & $0.1374^{*}$ & \multicolumn{2}{|c|}{$0.0833^{\text {ns }}$} & $0.0310^{\mathrm{ns}}$ \\
\hline BAP $x$ PPM ${ }^{\mathrm{TM}}$ & 9 & $0.0742^{\text {ns }}$ & \multicolumn{2}{|c|}{$0.1389^{\mathrm{ns}}$} & $0.2414^{\mathrm{ns}}$ \\
\hline Error & 32 & 0.0361 & \multicolumn{2}{|c|}{0.1110} & 0.1145 \\
\hline CV (\%) & & 36.15 & \multicolumn{2}{|c|}{38.08} & 47.67 \\
\hline \multirow{2}{*}{ Sources of variation } & \multirow{2}{*}{ DF } & \multicolumn{4}{|c|}{ Mean square } \\
\hline & & $\mathrm{BC}(\%)$ & $\mathrm{FC}(\%)$ & TCM (\%) & SE (\%) \\
\hline BAP & 3 & $0.0981^{\mathrm{ns}}$ & $0.1870 * *$ & $0.0667^{\mathrm{ns}}$ & $0.0492^{\text {ns }}$ \\
\hline $\mathrm{PPM}^{\mathrm{TM}}$ & 3 & $0.3565 * *$ & $0.0877^{*}$ & $1.1930 * *$ & $1.1012 * *$ \\
\hline $\mathrm{BAP} \times \mathrm{PPM}^{\mathrm{TM}}$ & 9 & $0.0689^{\mathrm{ns}}$ & $0.0369^{\mathrm{ns}}$ & $0.0774^{\mathrm{ns}}$ & $0.0895 *$ \\
\hline Error & 32 & 0.0352 & 0.0286 & 0.0373 & 0.0353 \\
\hline $\mathrm{CV}(\%)$ & & 37.31 & 22.20 & 17.19 & 43.04 \\
\hline
\end{tabular}

PEST: percentage of explants with shoots per treatment; NSE: average number of shoots per explant; LS: average length of shoots; BC: bacterial contamination; FC: fungal contamination; TMC: total microbial contamination; SE: surviving explants; DF: degrees of freedom; CV: coefficient of variation. ${ }^{\text {ns }}$ not significant; $* *$ significant at $1 \%$; * significant at $5 \%$. Percentage data transformed by $\operatorname{arc} \operatorname{sen} \sqrt{(x / 100)}$.

no effect of BAP on the average number of shoots per explant (Table 1). In none of the treatments the average number of shoots per explant was superior to one (Figure 1C).

Prutpongse \& Gavinlertvatana (1992), when evaluating the effect of BAP on nodal segments

A)
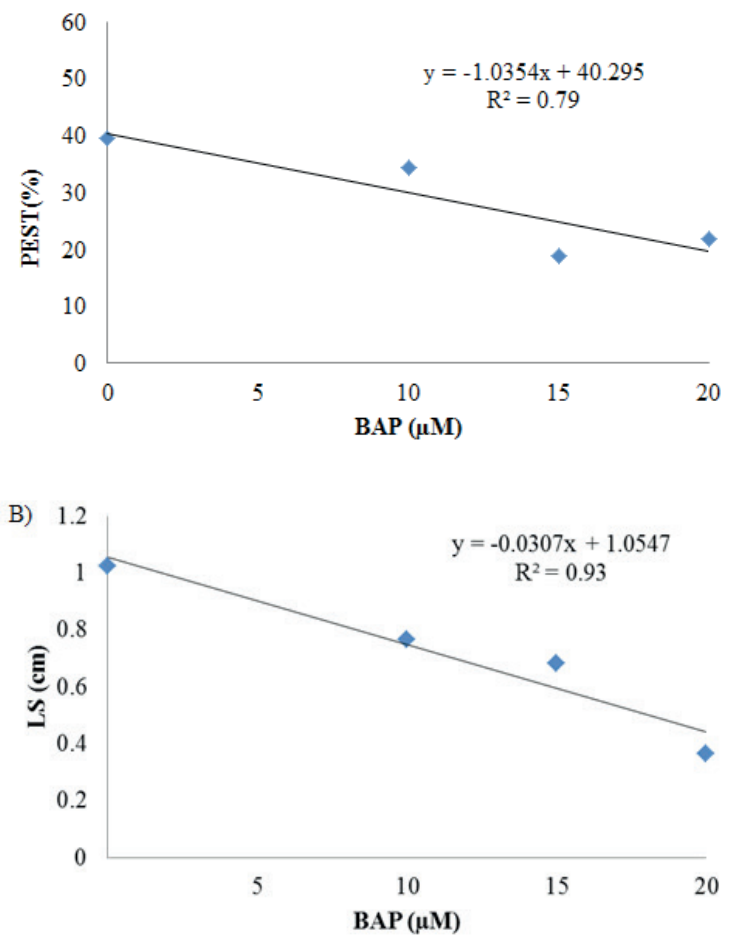

multiplication of 54 bamboo species (among them B. oldhamii), suggested that shoots can be obtained directly in nodal segments by the use of a culture medium supplemented with $22 \mu \mathrm{M}$ of BAP. This result differs from those obtained in the present study, where propagules were harvested from adult plants cultivated in the field. It is important to observe that the use of cytokinin is one of the factors that influence the development of shoots under in vitro conditions, and that the different responses obtained by different studies may reflect the role of other factors. These may be genetic and/ or environmental factors, inherent to the plant tissues used as explant source.

The $\mathrm{PPM}^{\mathrm{TM}}$ effect was significant for all variables of interest, except for the average number of shoots per explant and the average length of shoots

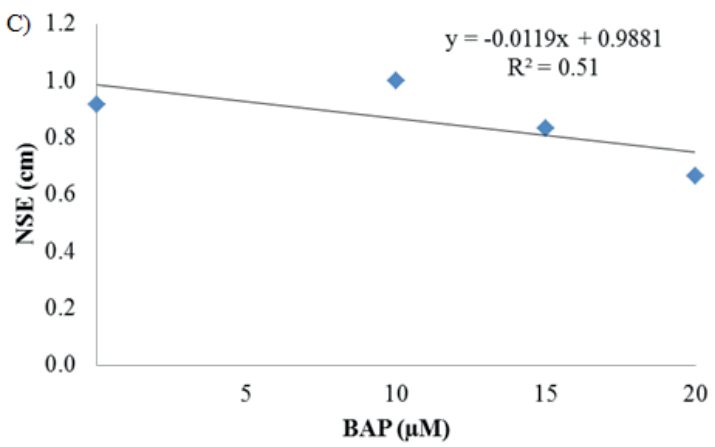

Figure 1. Sprouting in nodal segments of Bambusa oldhamii after 21 days of culture in MS medium supplemented with different 6-benzylaminopurine (BAP) concentrations. A) Percentage of explants with shoots per treatment (PEST); B) average length of shoots (LS); C) average number of shoots per explant (NSE). 
(Table 1). Linear regression models were fit for all the affected variables (Figures 2A to 2D). The treatment with $3 \mathrm{~mL} \mathrm{~L}^{-1}$ of $\mathrm{PPM}^{\mathrm{TM}}$, if compared to the control treatment, reduced the bacterial contamination from $44 \%$ to $16 \%$ (Figure $2 \mathrm{~A}$ ), the fungal contamination from $58 \%$ to $38 \%$ (Figure $2 \mathrm{~B}$ ) and the total microbial contamination from $99 \%$ to $53 \%$ (Figure $2 \mathrm{C}$ ). Based on these results, it can be concluded that the addition of $\mathrm{PPM}^{\mathrm{TM}}$ to the culture medium led to a significant reduction of microbial contamination, even though the complete inhibition of microorganisms was not achieved.
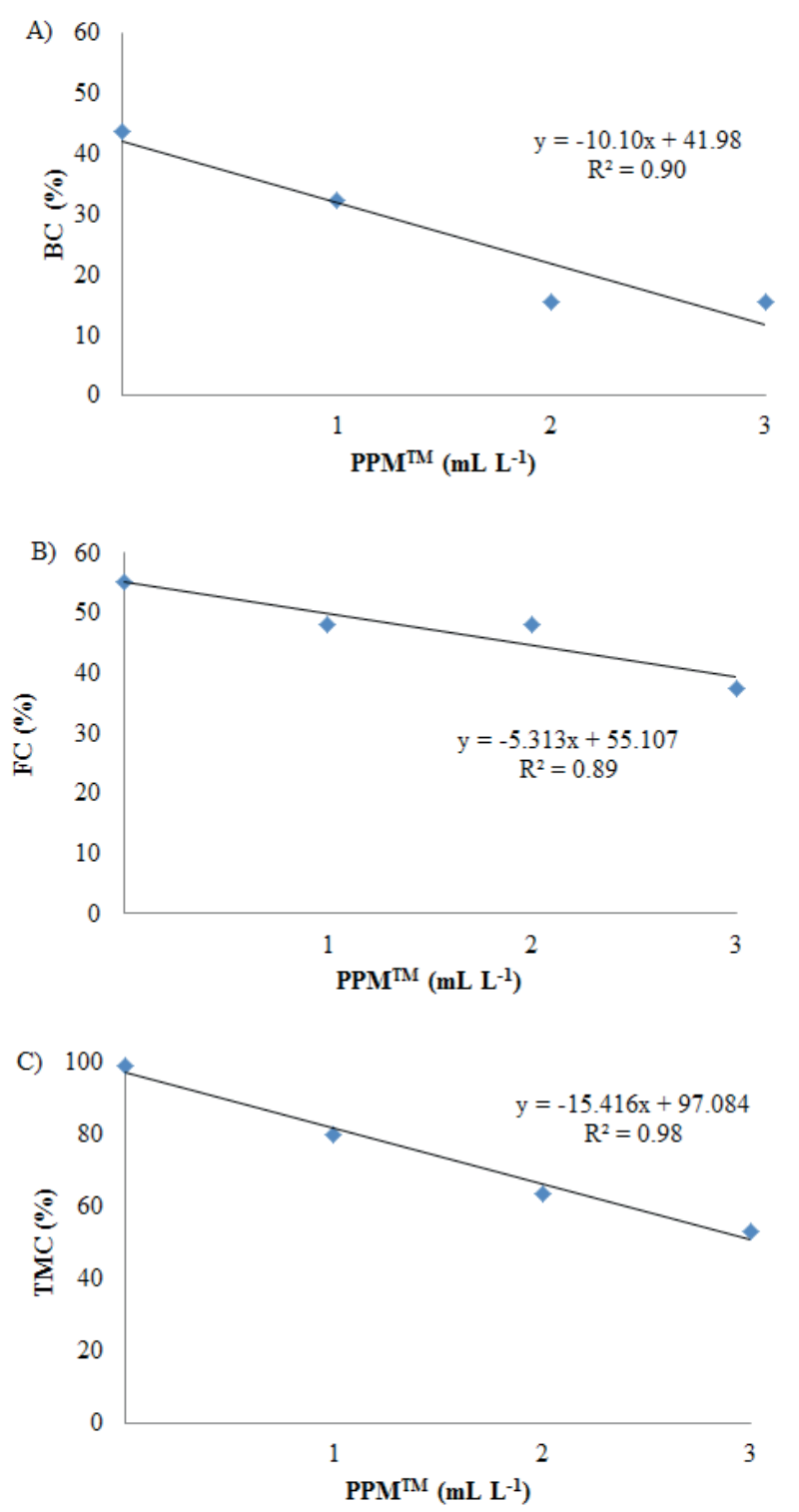

When the percentage of explants with shoots per treatment is considered, the highest rate was observed in the presence of $3 \mathrm{~mL} \mathrm{~L}^{-1}$ of $\mathrm{PPM}^{\mathrm{TM}}$ in the culture medium (Figure 2E). This result was likely due to the reduction of the total microbial contamination, which consequently led to a higher surviving rate (47\%; Figure 2D) and, therefore, opportunity to shoot development. Mudoi et al. (2014) observed the best results for microbial contamination control with the pretreatment of Bambusa nutans explants with alcohol $70 \%$, plus Tween 20 (5\%), $0.1 \%$ Mancozeb and $0.1 \%$ Gentamicin, which led to a final contamination percentage of $55 \%$ and a survival rate of $45 \%$. Their results were, therefore, similar to those reported in this study.

In previous studies, during the micropropagation of Bambusa balcooa, the presence of endophytic contaminants hindered the success of the establishment of in vitro cultures. In these studies, severe treatments applied for the removal of endophytic fungi using different antifungal compounds and commercial antimicrobial supplements were not fully effective (Tyagi et al. 2017).
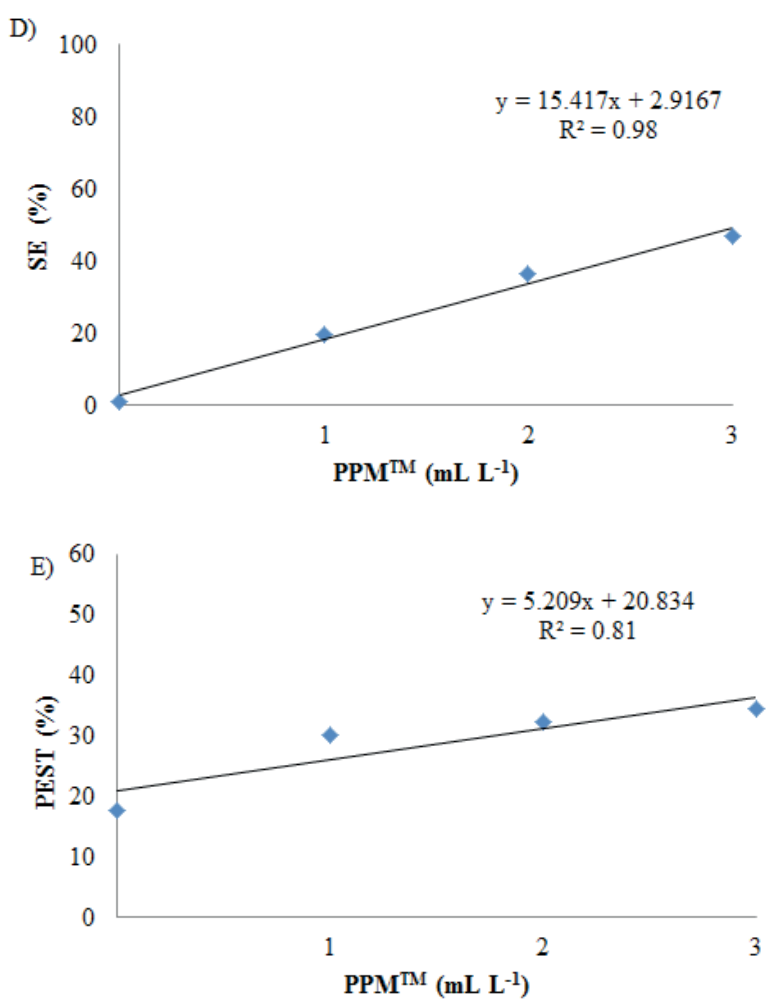

Figure 2. Effect of $\mathrm{PPM}^{\mathrm{TM}}$ on microbial contamination, surviving and percentage of explants with shoots per treatment, in nodal segments of Bambusa oldhamii after 21 days of in vitro culture in MS medium. A) Bacterial contamination (BC); B) fungal contamination (FC); C) total microbial contamination (TMC); D) surviving explants (SE); E) percentage of explants with shoots per treatment (PEST). 
In the second experiment of this study, the analysis of variance (Table 2) did not show significant differences among the evaluated BAP concentrations $(0 \mu \mathrm{M}, 2.5 \mu \mathrm{M}, 5 \mu \mathrm{M}$ and $7.5 \mu \mathrm{M})$ on the variables of interest. In general, the percentage of explants with shoots per treatment was $54 \%$, the average number of shoots per explant 1.2 and the average length of shoots $3.2 \mathrm{~cm}$.

With the addition of $4 \mathrm{~mL} \mathrm{~L}^{-1}$ of $\mathrm{PPM}^{\mathrm{TM}}$ to the culture medium, there was no bacterial contamination, while the fungal presence was visually observed in $49 \%$ of the explants (Table 2 ). $\mathrm{PPM}^{\mathrm{TM}}$ is a broad-spectrum biocide containing chloromethylisothiazolone and methylisothiazolone in its formulation (Compton \& Koch 2001). It is indicated for fungal cells inactivation, to prevent spores germination and, in high concentrations ( $2 \mathrm{~mL} \mathrm{~L}^{-1}$ for woody plants), to eliminate endogenous contamination in explants (PCT 2018). However, data from the present study indicate that the use of

Table 2. Effect of 6-benzylaminopurine (BAP) concentrations in Bambusa oldhamii explants after 21 days of in vitro culture in MS medium plus $4 \mathrm{~mL} \mathrm{~L}^{-1}$ of $\mathrm{PPM}^{\mathrm{TM}}$.

\begin{tabular}{ccccc}
\hline Treatment & \multicolumn{4}{c}{ Average } \\
\hline BAP $(\mu \mathrm{M})$ & PEST $(\%)$ & NSE & LS $(\mathrm{cm})$ & FC $(\%)$ \\
\hline 0.0 & 68 & 1.3 & 3.1 & 43 \\
2.5 & 33 & 1.1 & 3.0 & 55 \\
5.0 & 60 & 1.2 & 3.3 & 55 \\
7.5 & 55 & 1.2 & 3.4 & 45 \\
\hline Average & 54 & 1.2 & 3.2 & 49 \\
\hline CV (\%) & 26.29 & 16.87 & 23.99 & 29.83 \\
\hline PEST: percentage of explants with shoots per treatment; NSE: average number \\
of shoots per explant; LS: average length of shoots; FC: fungal contamination. \\
Untransformed percentage data.
\end{tabular}

$4 \mathrm{~mL} \mathrm{~L}^{-1}$, although visually efficient in controlling the bacterial growth, did not show the same efficiency in controlling the fungal growth in semisolid medium.

Under scanning electron microscopy, fungal hyphae were observed in the axillary buds (Figure 3A), both internally (Figures 3B and 3C) and externally (Figure 3D). The presence of fungal structures in the intercellular spaces hinders the decontamination of plant tissue, decreasing the effectiveness of the disinfestation protocols used to control the development of microorganisms in vitro.

As the level of fungal contamination remained an issue, even with the addition of $4 \mathrm{~mL} \mathrm{~L}^{-1}$ of $\mathrm{PPM}^{\mathrm{TM}}$ to the culture medium, the molecular identification of the contaminants was carried out aiming at the development of more effective decontamination protocols.

In order to obtain isolates for identification, after 28 days of culture, the test tubes with explants that showed fungal growth were categorized into 17 morphotypes, based on the colonies characteristics. After the purification of the isolates, it was possible to differentiate 11 organisms, which were identified by DNA sequencing using the ITS region sequences of rDNA (Table 3).

Bamboos are an important reservoir of microorganisms that must be extensively investigated (Morakotkarn et al. 2007). In the present study, several fungi were isolated from $B$. oldhamii cultivated in vitro (Table 3 ). Among those, the Wojnowiciella genus was observed. Currently, this genus comprises seven species isolated from leaf spots and branches of different hosts. Although it has been associated with disease symptoms, its pathogenicity remains to be proven (Marin-Felix

Table 3. Isolates of fungi obtained from Bambusa oldhamii explants cultured in vitro.

\begin{tabular}{clcc}
\hline Sample & \multicolumn{1}{c}{ Species } & Number of the isolate in the collection & Access on NCBI \\
\hline 1 & Wojnowiciella leptocarpi & CMRP3289 & NR 155973.1 \\
2 & Diaporthe sp. & CMRP3300 212356.1 \\
3 & Diaporthe novem & CMRP3294 & MG655176.1 \\
4 & Phaeosphariaceae sp. & CMRP3303 & MH178702.1 \\
5 & Leptosphaeria sp. & CMRP3291 & HM042314.1 \\
6 & Phoma herbarum & CMRP3287 & KU710251.1 \\
7 & Fusarium sp. & CMRP3297 & HQ696071.1 \\
8 & Fusarium graminearum & CMRP3301 & MH231314.1 \\
9 & Arthrinium kogelbergense & CMRP3302 & MG098297.1 \\
10 & Arthrinium kogelbergense & CMRP3304 & MG098297.1 \\
11 & Arthrinium arundinis & CMRP3292 & MH211222.1 \\
\hline
\end{tabular}

NCBI: National Center for Biotechnology Information. 


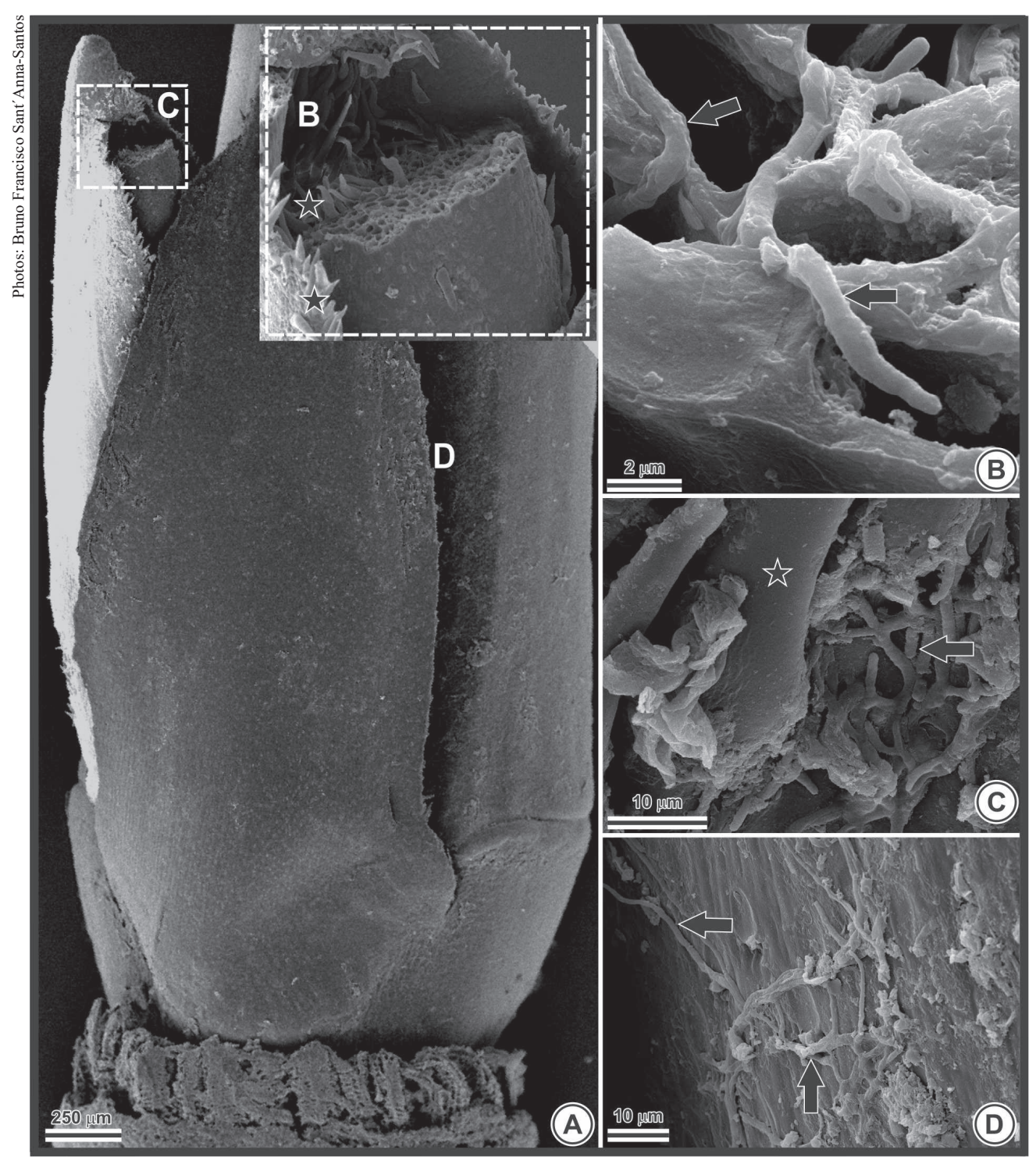

Figure 3. Photomicrography of a Bambusa oldhamii explant obtained by scanning electron microscopy. A) axillary bud. The letters B, C and $\mathrm{D}$ in the image indicate the approximate locations that have been enlarged in the complementary images; B) fungal hyphae housed inside cells (black arrows indicate hyphae); C and D) fungal hyphae (arrows) on the epidermis (C) and associated with trichomes (star) (D).

et al. 2019). Among the isolates, species of the Diaporthe genus (Phomopsis) were also observed, and these organisms have been frequently reported as plant pathogens, nonpathogenic endophytes or saprobes, commonly isolated from a wide range of hosts (Gomes et al. 2013).

The isolation of endophytic fungi from Phyllostachys spp. and Sasa spp. bamboos allowed the identification of eleven strains of the Pleosporales order, with many genus of reference, among them Leptosphaeria, Paraphaeosphaeria and Phoma (Morakotkarn et al. 2007). Phaeosphaeriaceae is a big and important family that includes economically relevant plant pathogens that may be endophytes or saprobes in plant hosts, especially in monocotyledons such as Poaceae (Phookamsak et al. 2014). Phoma herbarum Westend is found in this order and related to the occurrence of leaf spot of phoma (Mohanan 1997), while Leptosphaeria sp. is associated with symptoms of sugarcane ocular spot (O’Neill 1996).

Furthermore, fungi of the Fusarium and Arthrinium genera are common in bamboos (Morakotkarn et al. 2007) and are associated with bamboo rust, a disease that leads to the death of 
the culm (Mohanan 1997). Fusarium graminearum has been associated with diseases in corn and wheat, while Arthrinium arundinis was described as the causative agent of the brown stripe disease in Phyllostachys praecox culms (Chen et al. 2014).

A large number of fungi isolated from the in vitro culture of $B$. oldhamii are known as plant pathogens. However, nodal segments were obtained from apparently healthy field plants. According to Morakotkarn et al. (2007), the colonization of bamboo plants by endophytic fungi is extremely frequent, and some may act as latent pathogens in parts of their life cycle.

In this study, the explants were immersed in a solution containing $2 \mathrm{~g} \mathrm{~L}^{-1}$ of the Cercobin ${ }^{\circledR}$ systemic fungicide (thiophanate methyl) applied for $24 \mathrm{~h}$ before disinfection. However, this procedure was not efficient in controlling the fungal growth during the in vitro establishment of $B$. oldhammi. Thiophanate methyl is a terminal metabolite of carbendazim which has been reported to have a residual effect of 7-15 days (Balardin 2018). During the micropropagation of $B$. oldhamii in this study, fungal growth was observed after the first 15 days of culture, period when the residual effect of thiophanate methyl decreased and the incidence of explants with fungal contamination increased. The use of carbendazim fungicide at different concentrations and exposure periods was also tested for the aseptic treatment of Bambusa balcooa (Tyagi et al. 2017) and, as reported in this study, surface sterilization failed to remove the contamination.

\section{CONCLUSIONS}

1. In the in vitro establishment of Bambusa oldhamii from nodal segments obtained from adult trees cultivated in the field, the addition of BAP to the culture medium, at the concentrations and conditions of the experiment, do not induce the development of multiple shoots;

2. The use of $4 \mathrm{~mL} \mathrm{~L}^{-1}$ of $\mathrm{PPM}^{\mathrm{TM}}$ increases the surviving rate of the explants, inhibits the bacterial contamination and reduces the fungal contamination;

3. The sequencing ITS region of rDNA of endophytic fungi isolates associated to nodal segments of B. oldhamii in vitro culture identified the presence of Wojnowiciella leptocarpi, Diaporthe sp., Diaporthe novem, Phaeosphariaceae sp., Leptosphaeria sp., Phoma herbarum, Fusarium sp., Fusarium graminearum, Arthrinium kogelbergense and Arthrinium arundinis with $100 \%$ of similarity.

\section{ACKNOWLEDGMENTS}

The authors thank Dr. M. P. Guerra for the project initiative "Technologies for the Sustainable Development of the Bamboo Production Chain in Southern Brazil - subproject: macro and micropropagation and in vitro conservation of bamboo germplasm"; Dr. C. R. Sanquetta for providing the plant material; Dr. J. V. M. Bittencourt for laboratory support; Dr. L. A. Biasi for ideas and suggestions in the elaboration of the study; Dr. B. P. Brasileiro for advising on the statistical analysis; Dr. A. Bianchini for editing the manuscript; Centro de Microscopia Eletrônica of the Universidade Federal do Paraná for images; and Coordenação de Aperfeiçoamento de Pessoal de Nível Superior - Capes (Code 001) and MCTI for financial support.

\section{REFERENCES}

ABDULMINAM, A. H.; NIRMALA. C.; SHARMA, M. L. Control of in vitro contamination in bamboos. Plant Cell Biotechnology and Molecular Biology, v. 10, n. 3-4, p. 119-124, 2009.

BADALI, H. et al. Biodiversity of the genus Cladophialophora. Studies in Mycology, v. 61, n. 1, p. 175-191, 2008.

BALARDIN, R. Fungicidas sistêmicos: benzimidazóis, triazóis e estrobilurinas. 2015. Available at: $<$ https:// phytusclub.com/materiais-didaticos/fungicidassistemicos-benzimidazois-triazois-e-estrobilurinas/>. Access on: 30 Jun. 2018.

BRASIL. Decreto-lei n. ${ }^{\circ} 12.484$, de 8 de setembro de 2011. Política Nacional de Incentivo ao Manejo Sustentado e ao Cultivo do Bambu - PNMCB. Diário Oficial da República Federativa do Brasil, Poder Executivo, Brasília, DF, 9 set. 2011. Seção 1. p. 1.

CHEN, K. et al. First report of brown culm streak of Phyllostachys praecox caused by Arthrinium arundinis in Nanjing, China. Plant Disease, v. 98, n. 9, p. 274-1274, 2014.

CHEN, Y. et al. Identification of an NAP-like transcription factor BeNAC1 regulating leaf senescence in bamboo (Bambusa emeiensis 'Viridiflavus'). Physiologia Plantarum, v. 142, n. 4, p. 361-371, 2011.

COMPTON, M. E.; KOCH, J. M. Influence of plant preservative mixture (PPM) on adventitious organogenesis 
in melon, petunia, and tobacco. In vitro Cellular \& Developmental Biology - Plant, v. 37, n. 2, p. 259-261, 2001.

GOMES, R. R. et al. Diaporthe: a genus of endophytic, saprobic and plant pathogenic fungi. Persoonia, v. 31, n. 1, p. 1-41, 2013.

GOYAL, A. K.; SEN, A. In vitro regeneration of bamboos, the "green gold": an overview. Indian Journal of Biotechnology, v. 15, n. 1, p. 9-16, 2016.

HALL, T. A. BioEdit: a user-friendly biological sequence alignment editor and analysis program for Windows 95/98/NT. Nucleic Acids Symposium Series, v. 41, n. 1, p. 95-98, 1999.

ISLAM, M. S. et al. Clonal propagation of Bambusa vulgaris by leafy branch cuttings. Journal of Forestry Research, v. 22, n. 3, p. 387-392, 2011.

JOHANSEN, D. A. Plant microtechnique. London: McGraw-Hill Book Company, 1940.

LIN, C. et al. Improving multiple shoot proliferation in bamboo mosaic virus-free Bambusa oldhamii Munro propagation by liquid culture. Hortscience, v. 42, n. 5, p. 1243-1246, 2007.

MARIN-FELIX, Y. et al. Genera of phytopathogenic fungi: GOPHY 2. Studies in Mycology, v. 92, n. 1, p. 47133, 2019.

MISHRA, Y. et al. A micropropagation system for cloning of Bambusa tulda Roxb. Scientia Horticulturae, v. 115, n. 3, p. 315-318, 2008.

MOGNON, F. Avaliação comportamental do crescimento, biomassa e estoque de carbono em espécies de bambu. 2015. Tese (Doutorado em Engenharia Florestal) Universidade Federal do Paraná, Curitiba, 2015.

MOHANAN, C. Diseases of bamboos in Asia: an illustrated manual. New Delhi: International Network for Bamboo and Rattan, 1997.

MORAKOTKARN, D.; KAWASAKI, H.; SEKI, T. Molecular diversity of bamboo-associated fungi isolated from Japan. FEMS Microbiology Letters, v. 266, n. 1, p. 10-19, 2007.

MUDOI, K. D.; BORTHAKUR, M. In vitro micropropagation of Bambusa balcooa Roxb. through nodal explants from field-grown culms and scope for upscaling. Current Science, v. 96, n. 7, p. 962-966, 2009.

MUDOI, K. D.; SAIKIA, S. P.; BORTHAKUR, M. Effect of nodal positions, seasonal variations, shoot clump and growth regulators on micropropagation of commercially important bamboo, Bambusa nutans Wall. ex. Munro. African Journal of Biotechnology, v. 13, n. 19, p. 19611972, 2014.
MURASHIGE, T.; SKOOG, F. A. A revised medium for a rapid growth and bioassays with tobacco tissues cultures. Plant Physiology, v. 15, n. 3, p. 473-479, 1962.

NADHA, H. K. et al. Identification and elimination of bacterial contamination during in vitro propagation of Guadua angustifolia Kunth. Pharmacognosy Magazine, v. 8, n. 30, p. 93-97, 2012.

O'NEILL, N. R. Miscanthus blight, a new foliar disease of ornamental grasses and sugarcane incited by Leptosphaeria sp. and its anamorphic state Stagonospora sp. Plant Disease, v. 80, n. 9, p. 980-987, 1996.

PHOOKAMSAK, R. et al. Revision of Phaeosphaeriaceae. Fungal Diversity, n. 68, p. 159-238, 2014.

PLANT CELL TECHNOLOGIES (PCT). PPM ${ }^{T M}$ : plant preservative mixture product information. 2018. Available at: <http://www.plantcelltechnology.com/ppm-productinformation>. Access on: 01 May 2018.

PRUTPONGSE, P.; GAVINLERTVATANA, P. In vitro micropropagation of 54 species from 15 genera of bamboo. Hortscience, v. 27, n. 5, p. 453-454, 1992.

SHIRIN, F.; RANA, P. K. In vitro plantlet regeneration from nodal explants of field-grown culms in Bambusa glaucescens Willd. Plant Biotechnology Reports, v. 1, n. 3, p. 141-147, 2007.

Shouliang, C. et al. Flora of China, Poaceae. Systematic Biology, v. 56, n. 2, p. 365-367, 2007.

SILVA, F. A. S.; AZEVEDO, C. A. V. The Assistat software version 7.7 and its use in the analysis of experimental data. African Journal of Agricultural Research, v. 11, n. 39, p. 3733-3740, 2016.

THIRUVENGADAM, M.; REKHA, K. T.; CHUNG, I. M. Rapid in vitro micropropagation of Bambusa oldhamii Munro. Philippines Agricultural Scientist, v. 94, n. 1, p. 7-13, 2011.

TORRES, G. R. C.; HOULlOU, L. M.; SOUZA, R. A. Control of contaminants during introduction and establishment of Bambusa vulgaris in vitro. Research in Biotechnology, v. 7, n. 1, p. 58-67, 2016.

TYAGI, B.; TEWARI, S.; DUBEY, A. Biochemical characterization of fungus isolated during in vitro propagation of Bambusa balcooa. Pharmacognosy Magazine, v. 13, n. 52, p. S775-S779, 2017.

VICENTE, V. A. et al. Environmental isolation of black yeast-like fungi involved in human infection. Studies in Mycology, v. 61, n. 1, p. 137-144, 2008.

YEH, M. L.; CHANG, W. C. Plant regeneration through somatic embryogenesis in callus culture of green bamboo (Bambusa oldhamii Munro). Theoretical and Applied Genetics, v. 73, n. 2, p. 161-163, 1986. 